\title{
Faktor Risiko Sepsis Awitan Dini pada Neonatus
}

\author{
Risk Factors of Early Onset Sepsis of the Newborn \\ Eko Sulistijono, Brigitta Ida RVC, Siti Lintang K, Astrid Kristina K \\ Laboratorium Ilmu Kesehatan Anak Rumah Sakit Umum Dr. Saiful Anwar Malang
}

\begin{abstract}
ABSTRAK
Faktor risiko maternal pada sepsis neonatal adalah ketuban pecah dini (KPD), demam pada ibu dua minggu sebelum kelahiran, cairan mekoneal yang bau dan persalinan dengan tindakan, sedangkan faktor risiko pada janin adalah berat lahir, usia kehamilan dan skor apgar. Penelitian ini dilakukan untuk mengidentifikaso prevalensi, karakteristik dan hubungan antara faktor risiko maternal dan fetus dengan terjadinya sepsis awitan dini. Strudi dilakukan pada Juli hingga Desember 2008 dengan menggunakan data rekam medis pasien yang memenuhi kriteria. Data faktor risiko ibu dan janin dianalisis dengan uji Chi-square. Hasil menunjukkan bahwa dari 69 pasien yang memenuhi kriteria didapatkan 45 pasien yang terbukti sepsis, dan 24 pasien yang meskipun menunjukkan tanda klinis sepsis namun pemeriksaan kultur darah negatif. Faktor risiko maternal yang menunjukkan hubungan signifikan adalah ketuban pecah dini $(p=0,017,0 R=3,466)$ dan faktor risiko janin adalah berat lahir rendah $(p=0,034, O R=7,441)$ dan skor apgar menit pertama $<7(p<0,001)$; $\mathrm{OR}=9,1)$. Dapat disimpulkan bahwa ketuban pecah dini, berat lahir yang rendah serta skor apgar $<7$ meningkatkan risiko terjadi sepsis awitan dini pada neonates.
\end{abstract}

Kata Kunci: Faktor risiko, ibu, janin, sepsis awitan dini

\section{ABSTRACT}

The maternal risk factors of neonatal sepsis are premature rupture membrane, maternal fever in 2 weeks before birth, meconeal and smelly amniotic fluid and instrumental delivery, while fetal risk factors are birth weight, gestational age and apgar score. The objective of this study was to find out the prevalence, characteristics and correlation of maternal and fetal risk factors of proven early onset sepsis of the newborn. Study was conducted from July 2008 to December 2008 with consecutive sampling. Fetal and maternal risk factors were further tested using Chi-square test. Identified from 69 patients who fulfilled inclusion criteria, forty five (45) subjects were proven sepsis and 24 patients had signs of neonatal sepsis though negative blood cutures. Risk factors showed significant results were maternal factor of early rupture membrane $(p=0,017, O R=3,466)$, fetal factors of low birth weight $(p=0,034,0 R=7,441)$ and first minute Apgar score $<7$ $(p=0,000 ; O R=9,1)$. It can be concluded that early rupture membrane, low birth weight and Apgar score $<7$ is the risk of proven earlyonset sepsis.

Keywords: Early onset sepsis, fetal, riskfactors, maternal

Jurnal Kedokteran Brawijaya, Vol. 27, No. 4, Agustus 2013; Korespondensi: Eko Sulistijono. Laboratorium Ilmu Kesehatan Anak Rumah Sakit Umum Dr. Saiful Anwar, Jl. Jaksa Agung Suprapto 2 Malang Telp. (0341) 362101 Email: ika_fkub@yahoo.com 


\section{PENDAHULUAN}

Sepsis neonatorum adalah sindroma klinis dari kelainan sistemik yang disebabkan oleh bakteremia pada umur 28 hari pertama $(1,2)$. Manifestasi klinis sepsis neonatorum tidak spesifik, kadang-kadang gejalanya tidak menunjukkan tanda-tanda infeksi (1-5). Angka kejadian sepsis neonatorum adalah 1-10 per 1000 bayi lahir hidup dan angkanya meningkat 13-27 per 1000 bayi lahir hidup pada bayi dengan berat lahir rendah (6). Pada bayi lakilaki risiko sepsis 2 kali lebih besar dari bayi perempuan. Kejadian sepsis juga meningkat pada bayi kurang bulan (BKB) (7).

Beberapa faktor yang terlibat pada sepsis neonatum antara lain sistem imun bayi baru lahir yang masih imatur atau belum matang, penurunan aktivitas fagosit leukosit, penurunan produksi sitokin, dan lemahnya sistem imun humoral. Barier alamiah kulit pada bayi juga tipis dan lemah. Berbagai faktor maternal, fetal, dan lingkungan juga ikut terlibat dalam terjadinya sepsis pada bayi baru lahir. Faktor dari janin meliputi berat badan lahir, usia kehamilan, dan Apgar score $(8,9)$. Faktor-faktor maternal tersebut antara lain ketuban pecah dini (KPD), demam pada ibu dalam 2 minggu sebelum melahirkan, ketuban mekoneal dan berbau, dan persalinan menggunakan alat (instrumental delivery). Meskipun demikian banyak literatur tidak menunjukkan secara jelas efek faktor-faktor tersebut dalam terjadinya sepsis pada bayi baru lahir tersebut (8).

Diagnosa sepsis pada bayi baru lahir berdasarkan gejala klinis meliputi, keadaan umum (not doing well, malas minum, hipertermia/hipotermia, sklerema, edema), sistem susunan saraf pusat (hipotoni, irritable, kejang, letargi, high-pitched cry, tremor, fontanella cembung), sistem saluran nafas (pernafaan tidak teratur, apnea, takipnea, sesak, sianosis), sistem kardiovaskuler (takikardia/bradikardia, akral dingin, syok), sistem saluran pencernaan (retensi lambung, hepatomegali, diare, muntah, perut kembung), dan sistem hematologi (kuning, pucat, splenomegali, petekiae, purpura, perdarahan). Hasil laboratorium darah lengkap menunjukkan leukopenia $(<5000 / \mathrm{mm} 3)$ dan rasio stab dan neutrofil $>0,2$, dapat membantu diagnosis. Pemeriksaan C-Reactive Protein menunjukkan peningkatan oleh karena adanya proses inflamasi yang disebabkan oleh infeksi atau kerusakan jaringan (10-13). Diagnosis sepsis pada bayi baru lahir dikategorikan menjadi 3, yaitu possible/suspect sepsis (bila terdapat gejala klinik dari 6 kelompok gejala klinik diatas), probable sepsis (terdapat 3 gejala klinik dan adanya kelainan laboratorium), serta proven sepsis (terdapat 3 gejala klinik dan kultur darah yang positif) (14).

Manifestasi klinis sepsis pada bayi baru lahir berdasarkan patofisiologi dan waktu perjalanannya dibagi dua, yaitu sepsis awitan dini (terjadi pada 3 hari pertama setelah lahir) dan sepsis awitan lanjut ( timbul setelah usia 3 hari) (15). Penelitian ini bertujuan untuk melihat keterlibatan faktor-faktor maternal, janin, dan lingkungan dalam terjadinya sepsis pada bayi baru lahir. Pada negara berkembang seperti Indonesia, dengan fasilitas hasil laboratorium yang cepat sangat terbatas, identifikasi faktor-faktor risiko dan penatalaksanaan yang lebih awal dapat menurunkan angka kesakitan dan kematian.

\section{METODE}

Penelitian ini bersifat retrospektif dengan mengambil data melalui rekam medis pasien antara bulan Juli 2008 sampai dengan Desember 2008. Kriteria inklusinya meliputi bayi baru lahir yang didiagnosa sepsis sampai dengan usia 3 hari di ruang perawatan perinatologi Rumah Sakit Dr. Saiful Anwar Malang antara bulan Juli-Desember 2008. Bayi baru lahir didiagnosa sepsis secara klinis dan laboratorium, bila didapatkan minimal dua dari hasil laboratorium berikut, yaitu leukosit total $<5000 / \mathrm{mm} 3$, stab $\geq 20 \%$, LED (Laju Endap Darah) $\geq 15 \mathrm{~mm} / \mathrm{jam}, C$-reactive protein $>6 \mathrm{mg} / \mathrm{dL}$ dan Absolute Neutrophil Count (ANC) $<1500 / \mathrm{mm} 3$. Semua subjek penelitian dilahirkan di RS dr. Saiful Anwar Malang dan dilakukan evaluasi keterlibatan faktor maternal dan janin terhadap terjadinya sepsis.

Sebanyak 96 kasus sepsis neonatal terkumpul dan 27 kasus dikeluarkan dari penelitian karena tidak memenuhi kriteria inklusi dan memenuhi kriteria eksklusi. Kriteria eksklusi meliputi data-data faktor risiko dan hasil kultur darah yang tidak tercatat di dalam rekam medis, bayi-bayi dengan malformasi kongenital mayor, dan berat badan lahir $\leq 1000$ gram.

Usia ibu dibagi menjadi dua kelompok yaitu usia $<20$ tahun dan $\geq 20$ tahun, status pendidikan dibagi menjadi 2, SDSMP (iliterate) dan SMA-S1 (literate). Paritas dibagi menjadi primigravida dan multigravida (pernah melahirkan lebih dari 1 kali), cara kelahiran dibagi 2 yaitu secara vaginal (spontan belakang kepala atau spontan bracht) dan Sectio Caesarea Transperitonealis Profunda (SCTP) (instrumental). Definisi ketuban pecah dini (KPD) yang dipakai adalah 1 jam setelah ketuban pecah, tidak diikuti tanda-tanda melahirkan. Adanya hipertensi saat hamil, preeklamsia, ataupun eklamsia merupakan salah satu faktor maternal yang dievaluasi pada penelitian ini. Definisi bayi kurang bulan adalah jika usia kehamilan $<37$ minggu. Kedua variabel (bebas dan tergantung) pada penelitian ini merupakan data kategorikal (skala nominal dan ordinal) dengan nilai expected kurang dari $5<20 \%$ sehingga uji statistik yang digunakan adalah uji Chi-square. Untuk melihat berapa besar faktor risiko mempengaruhi terjadinya proven sepsis (sepsis dengan hasil kultur darah positif), digunakan nilai rasio odds. Analisis data menggunakan SPSS 17, nilai $p<0,05$ dianggap signifikan.

\section{HASIL}

Dari total 96 pasien bayi baru lahir yang didiagnosa secara klinis dan laboratorium antara Juli-Desember 2008, 69 pasien memenuhi kriteria penelitian. Faktor-faktor janin antara lain, berat badan lahir, jenis kelamin bayi, Apgar score menit pertama, dan usia kehamilan. Kasus dengan kultur darah positif ditemukan pada 34 bayi baru lahir dengan sepsis. Mikroorganisme atau bakteri tersebut antara lain Stafilokokus koagulase negatif (17/50\%), Enterobacter gergoviae (6/18\%), Klebsiella pneumonia (5/15\%), Eschericia coli (3/8\%), Pseudomonas aerogenosa (2/6\%), dan Acinetobacter (1/3\%). Pada 35 kasus, diagnosis sepsis ditegakkan berdasarkan manifestasi klinis dan hasil laboratorium.

Tabel 1 memperlihatkan berbagai macam faktor risiko baik dari ibu maupun janin pada sepsis bayi baru lahir. Faktor maternal (ibu) yang menunjukkan peran signifikan adalah adanya ketuban pecah dini $(p=0,017, O R=3,5)$. Hal ini menunjukkan bahwa riwayat adanya KPD berisiko 3,5 kali terjadi sepsis pada bayi yang dilahirkan dibandingkan ibu tanpa KPD, sedangkan faktor-faktor maternal lain tidak menunjukkan hasil signifikan. Adanya ketuban yang bercampur mekoneal, hipertensi pada kehamilan, dan 
ketuban pecah dini $(p=0,017, O R=3,5)$, berisiko 3,5 kali terjadi sepsis pada bayi yang dilahirkan dibandingkan ibuibu tanpa KPD. Faktor-faktor maternal lain tidak menunjukkan hasil signifikan. Adanya ketuban yang bercampur mekoneal, hipertensi pada kehamilan, dan perdarahan antepartum sedikit lebih berisiko terjadi proven sepsis pada bayi baru lahir.

Subjek penelitian dengan berat badan lahir rendah dengan proven sepsis sebanyak 32 bayi dan unproven sepsis sebanyak 1 bayi. Hasil penelitian menunjukkan bahwa berat badan lahir rendah (<2500 gram) berisiko 7,4 kali terjadi proven sepsis $(p=0,034)$. Nilai Apgar score menit pertama $<7$ juga menunjukkan hasil statistik yang signifikan $(p<0,001)$, dengan OR 9,1 sehingga bayi-bayi dengan Apgar score $<7$ berisiko 9 kali lipat mengalami proven sepsis awitan dini dibandingkan bayi-bayi yang lahir dengan Apgar score $>7$. Bayi kurang bulan (preterm infant) juga menunjukkan risiko sebesar 7,4 kali mengalami proven sepsis awitan dini jika dibandingkan bayi-bayi cukup bulan $(p=0,05, O R=7,4)$. Faktor jenis kelamin pria hanya meningkatkan risiko sebesar 1,2 kali dibandingkan jenis kelamin perempuan $(p=0,729$, $\mathrm{OR}=1,2$ ).

Tabel 1. Faktor-faktor risiko ibu (maternal) dan janin pada sepsis bayi awitan dini

\begin{tabular}{|c|c|c|c|}
\hline Parameter & Variabel & $\begin{array}{l}\text { Kasus } \\
\text { (Proven } \\
\text { Sepsis) }\end{array}$ & $\begin{array}{l}\text { Statistical } \\
\text { Significance }\end{array}$ \\
\hline \multirow[t]{2}{*}{ Usia ibu } & $<20$ tahun & 11 & $p=0,240$ \\
\hline & $\geq 20$ tahun & 34 & $O R=2,265$ \\
\hline Status & SD -SMP (Iliterate) & 26 & $p=0,773$ \\
\hline pendidikan & SMA-S1 (Literate) & 19 & $\mathrm{OR}=1,158$ \\
\hline \multirow[t]{2}{*}{ Paritas } & Primigravida & 23 & $p=0,825$ \\
\hline & Multigravida & 22 & $\mathrm{OR}=0,627$ \\
\hline Mode of & Vaginal (SpTB) & 15 & $p=0,120$ \\
\hline Delivery & SCTP/instrumental & 30 & $\mathrm{OR}=0,833$ \\
\hline \multirow[t]{2}{*}{ KPD/PROM } & Ya & 32 & $p=0,017$ \\
\hline & Tidak & 13 & $O R=3,466$ \\
\hline Ketuban & Ya & 18 & $p=0,586$ \\
\hline mekoneal & Tidak & 27 & $\mathrm{OR}=1,333$ \\
\hline \multirow[t]{2}{*}{ Maternal fever } & Ya & 9 & $p=0,396$ \\
\hline & Tidak & 36 & $O R=0,607$ \\
\hline HT/PE/Eklamsi & Ya & 16 & $p=0,288$ \\
\hline $\mathrm{a}$ & Tidak & 27 & $\mathrm{OR}=1,340$ \\
\hline \multirow[t]{2}{*}{ APB } & Ya & 5 & $p=0,951$ \\
\hline & Tidak & 45 & $\mathrm{OR}=2,875$ \\
\hline \multirow[t]{2}{*}{ Berat lahir } & $<2,5 \mathrm{Kg}$ & 11 & $p=0,034$ \\
\hline & $\geq 2,5 \mathrm{Kg}$ & 34 & $\mathrm{OR}=7,441$ \\
\hline Apgar score (1 & $<7$ & 39 & $p=0,000$ \\
\hline menit) & $\geq 7$ & 6 & $O R=9,100$ \\
\hline \multirow[t]{4}{*}{ Usia kehamilan } & Preterm/kurang & 11 & $p=0,05$ \\
\hline & bulan & 34 & $\mathrm{OR}=7,441$ \\
\hline & Aterm/cukup & & \\
\hline & bulan & & \\
\hline \multirow[t]{2}{*}{ Jenis kelamin } & Pria & 30 & $p=0,729$ \\
\hline & Wanita & 15 & $\mathrm{OR}=1,2$ \\
\hline
\end{tabular}

\section{DISKUSI}

Hasil penelitian ini menunjukkan bahwa faktor maternal berupa ketuban pecah dini dan faktor janin (berat lahir rendah, kurang bulan, dan Apgar score <7) merupakan faktor risiko yang meningkatkan terjadinya proven sepsis awitan dini pada bayi baru lahir. Pada penelitian Wong et al didapatkan hasil penelitian yang sama, ditambah adanya ketuban bercampur mekoneal juga berperan signifikan pasa sepsis awitan dini (16).

Adanya ketuban pecah dini meningkatkan risiko terjadinya proven sepsis awitan dini oleh karena penyebaran infeksi secara asending. Pada penelitian ini, 32 (46\%) bayi yang mengalami proven sepsis awitan dini, ibunya mengalami KPD sebelum melahirkan. Penelitian Wong et al, Oddie et $a l$, dan Betty $C$, juga menunjukkan hasil yang sama $(16,18)$. Penelitian Wong dan Betty juga memperlihatkan bahwa adanya ketuban mekoneal meningkatkan faktor risiko terjadinya sepsis, tetapi hasil penelitian ini tidak menunjukkan hasil statistik yang signifikan, hanya memperlihatkan peningkatan faktor risiko sebesar 1,3 kali dibandingkan bayi-bayi yang lahir dengan ketuban jernih. Hasil penelitian Oddie et al juga menunjukkan hasil yang sama (17). Fereiz et al dan Bhutta et al mengemukakan adanya faktor-faktor risiko maternal lain meliputi primigravida, kehamilan usia muda, preeklamsia, infeksi saluran kemih dan demam pada ibu $(19,20)$.

Faktor risiko fetal (janin) pada penelitian ini yang bernilai signifikan meliputi, berat lahir rendah, prematuritas (kurang bulan), dan Apgar score $>7$ saat menit pertama. Bayi-bayi prematur dan berat lahir rendah memiliki sistem imun yang masih belum matang (relatively immune deficient) sehingga bisa menjadi faktor predisposisi atau memudahkan terjadinya infeksi. Bayi yang lahir dengan Apgar score menit pertama $<7$ memerlukan prosedur intervensi yang lebih (instrumental procedure) yang bisa meningkatkan risiko terjadinya infeksi nosokomial. Penelitian Oddie et al, Betty, dan Soman et al juga menunjukkan hasil yang sama $(18,19,21)$. Penelitian Wong et al menambahkan bahwa Apgar score yang rendah saat menit pertama meningkatkan kebutuhan prosedur ventilasi mekanik dan pemasangan kateter umbilikal sehingga meningkatkan risiko terjadinya sepsis awitan dini pada bayi baru lahir (16).

Hasil kultur positif didapatkan pada 45 (65\%) bayi subjek penelitian. Bakteri yang paling sering menyebabkan sepsis pada bayi baru lahir di Rumah Sakit Dr. Saiful Anwar antara lain, Stafilokokus koagulase Negatif (17/50\%), Enterobacter gergoviae (6/18\%), Klebsiella pneumonia (5/15\%), Eschericia coli (3/8\%), Pseudomonas aerogenosa (2/6\%), dan Acinetobacter (1/3\%). Hasil ini tidak jauh berbeda dengan laporan dari NNPD pada tahun 2007, yang menunjukkan Klebsiella pneumonia dan Stafilokokus aureus sebagai penyebab utama sepsis pada bayi baru lahir di India. Penelitian Betty melaporkan Pseudomonas aerogenosa dan Klebsiella pneumonia sebagai penyebab paling banyak sepsis awitan dini pada bayi baru lahir. Adanya perbedaan pola kuman ini menunjukkan bahwa masing-masing rumah sakit harus mempunyai dan membuat peta kuman sendiri agar pengobatan sesuai antibiotika yang sensitif dapat dilakukan sehingga angka kesakitan dan kematian sepsis pada bayi baru lahir dapat diturunkan.

Hasil penelitian ini menunjukkan faktor maternal (ketuban 
pecah dini), prematuritas, berat lahir rendah, dan apgar score menit pertama $<7$ merupakan faktor risiko yang kuat terjadinya sepsis pada bayi baru lahir. Oleh karena itu pada

\section{DAFTAR PUSTAKA}

1. Gomella TL, Cunningham MD, Eyal FG, and Zenk KE. Infectious Diseases. In: Gomella TL (Eds). Neonatology: Management, Procedures, On-call Problems, Diseases, Drugs 8th edition. New York: Lange Medical Books/McGraw-Hill; 2006; p. 408-414.

2. Gotoff SP. Infection of the Neonatal Infant. In: Behrman RF (Eds). Nelson Text Book of Pediatric 23rd edition. Philadhelphia: WB Saunders Co; 2000; p. 538552.

3. Mccracken GH and Freii B. Bacterial and Viral Infections of the Newborn. In: Avery GB (Eds). Neonatology: Pathophysiology and Management of the Newborn 3rd ed. Philadhelphia: JB Lippincott Co; 1987; p. 917-30.

4. Speck WT, Aranoff SC, and Fanaroff AA. Neonatal Infection. In: Klauss $\mathrm{MH}$ (Eds). Care of the High Risk Neonate 3rd edition. Philadhelphia: WB Saunders Co; 1996: p. 262-85.

5. Klein JO and Marcy SM. Bacterial Sepsis and Meningitis. In: Remington JS (Eds). Infectious Diseases of the Fetus and Newborn Infants 5th edition. Philadelphia: WB Saunders Co; 2001; p. 1356-1364.

6. Stoll BJ, Holman RC and Schuchat A. Decline in SepsisAssociated Neonatal and Infant Deaths in the United States, 1979 through 1994. Pediatrics. 1998; 102(2): e18.

7. Isaacs D and Moxon ER. Neonatal Infection. In: Isaacs D and Moxon ER. Oxford: Butterworth-Heinemann Ltd; 2001; p. 1-56.

8. Sarwono E, Damanik S, Indarso F, dan Harianto A. Pedoman Diagnosa dan Terapi Neonatologi RSUD dr. Soetomo Surabaya. 2008; hal. 11-16.

9. Guerina NG. Bacterial and Fungal Infections. In: Cloherty JP (Eds). Manual of Neonatal Care 14th edition. Philadelphia: Lippincott Williams \& Wilkins; 2008; p. 271-307.

10. Powell KR. Sepsis and Shock. In: Behrman RF, Kleigman RN and Jenson HB (Eds). Nelson Text Book of Pediatric setiap bayi baru lahir harus dilakukan skrining dan observasi tanda-tanda klinis dan laboratorium terjadinya sepsis dan dipertimbangkan diberikan antibiotika lebih awal.

16th edition. Philadelphia: WB Saunders Co; 2000; p. 747-751.

11. Gerdes JS. Diagnosis and Management of Bacterial Infections in the Neonate. Pediatric Clinics of North America. 2004; 51(4): 939-959.

12. Stoll BJ. The Global Impact of Infection. Clinics in Perinatolology.1997; 24(4): 1-21.

13. Kawamura M and Nishida H. The Usefulness of Serial Creactive Protein and White Cell Count with Differential in Neonates at Risk for Septicemia. Acta Paediatrica. 1995; 84(2):10-13.

14. Moodi N and Carr R. Promising Stratagems for Reducing the Burden of Neonatal Sepsis. Archieves of Disease in Childhood: Fetal \& Neonatal. 2000; 83:150153.

15. Aggrawal R, Sarkar N, Deorari AK, and Paul VK. Sepsis in the Newborn. Indian Journal of Pediatrics. 2001; 68: 1143-1147.

16. Wong NA, Hunt LP, and Marlow N. Risk Factors for Developing Neonatal Septicemia at a Malaysian Hospital. Journal of Tropical Pediatrics. 1997; 43(1): 54-58.

17. Oddie S and Embleton ND. Risk Factors for Early Onset Neonatal Group B Streptococcal Sepsis: Case Control Study. British Medical Journal. 2002; 325(7359); 308.

18. Betty C and Sohil K. Early Onset Neonatal Sepsis. Indian Journal of Pediatrics. 2005; 72: 23-26.

19. Fereiz BJ and Mac Cracken GH. Acute Infections. In: Neonatal Pathology and Management of Newborn 5th edition. 1999; 1189-1304.

20. Bhutta ZA and Yusuf K. Early Onset Neonatal Sepsis in Pakistan: A Case Control Study of Risk Factors in a Birth Cohort. American Journal of Perinatology. 1997; 14: 577-581.

21. Soman M, Green B, and Daling J. Risk Factors for Early Neonatal Sepsis. American Journal of Epidemiology. 1985; 121(5): 712-719. 